\title{
Orman Zararılıarı ile Mücadele Faaliyetlerine Verilen Önem ile Ayrılan Zaman Düzeyinin Belirlenmesi (Denizli Orman İşletme Müdürlüğü Örneği)
}

\author{
İsmail Şafak ${ }^{1,{ }^{\star}}$, Emre Göksu${ }^{1}$ \\ ${ }^{1}$ Ege Ormancılık Araştırma Enstitüsü Müdürlüğü, Urla, İzmir.
}

\section{Özet}

Bu çalışmada, orman zararlıları ile mücadele konularında Denizli Orman Işsletme Müdürlüğünde yürütülen işlerde mevsimsel açıdan faaliyetlere/işlere verilen önem ve bunlara ayrılan zaman yüzdesi bakımından oluşan farklıllklar araştırılmıştır. Anket formları kullanılarak orman muhafaza memurları ile orman mühendislerinin tamamının mevsimsel olarak görüşleri alınmıştır. Böylece, mevsimsel olarak iş çeşitlerine atfedilen önem ile her bir iş çeşidi için ayrllan zaman yüzdesi elde edilmiştir. Anketlerde harcanan zaman yüzdesi her bir soru için \% 100 üzerinden değerlendirilmiştir. Her bir iş çeşidine verilen önem düzeyinin değerlendirilmesinde ise dokuz dereceli Likert ölçeğinden yararlanılmıştır.14 ormancllı faaliyeti genel olarak değerlendirildiğinde, koruma ve orman suçlarının tespitine yönelik faaliyetler 8.3 puan ile en fazla önem verilen konu olarak belirlenmiştir. Ormanların hava kirliliği üzerindeki etkilerinin değerlendirilmesi ve izlenmesine yönelik uluslararası işbirliği programı (ICP) kapsamındaki faaliyetler (5,0) ise en az önem verilmektedir. Ayrılan zaman açısından incelendiğinde koruma ve orman suçlarının tespitine yönelik faaliyetlere en fazla zaman (\%17.7), karantina tedbirleri ve uygulamalarının yürütülmesini sağlamaya yönelik faaliyetlere ise en az zaman (\%3.5) ayrlmaktadır

\section{Anahtar Sözcükler}

Orman Zararlıları İle Mücadele, Orman İşletme Müdürlüğü, Kruskal-Wallis H Testi, Mann-Whitney U Testi

\section{Determination of Importance Given to Control Forest Pest and Time Allocated to Them (A Case Study of Denizli Forest Enterprise Directorate)}

\begin{abstract}
In this study, the differences between in terms of the importance given to seasonal activities/works and the percentage of time allocated to them were investigated on the field of control of forest pests in Denizli Forest Enterprise Directorate. It was taken the seasonal views of all forest protection officers and forest engineers by the questionnaire forms. Thus, the importance attributed to the types of work and the percentage of allocated time for each type of work were obtained seasonally. Percentage of time spent in the questionnaires was evaluated at 100\% for each question. In order to evaluate the level of importance given to each type of work, the nine-point Likert scale was used. When 14 forestry activities were evaluated generally, protection and forest crimes were determined as the most important subject with average 8.3 points. The activities under the International Cooperative Programme on Assessment and Monitoring of Air Pollution Effects on Forest (ICP) (5.0) were of minimum importance. When investigated in terms of allocated time, activities for determining the protection and forest crime were maximum spent of time (17.7\%) and activities for quarantine measures and practices were minimum spent of time (3.5\%).
\end{abstract}

$\underline{\text { Keywords }}$

Control of Forest Pests, Forest Enterprise Directorate, The Kruskal-Wallis H Test, The Mann-Whitney U Test

\section{Giriş}

Ormancılık, doğa koşullarının etkisi altında gerçekleşen aynı zamanda da sosyal yönü olan bir uğraştır. Bu uğraşı gerçekleştiren orman mühendisleri, ormancılık örgütüne yüklenmiş geniş sorumluluk alanlarında görev yapmaktadır. Çalışma koşulları, farklı disiplinlerde bilgi birikimine ve beceriye sahip olmayı gerektirmekte, sorumlulukları ise toplumun gelişen ve değişen taleplerini her zaman karşılamak durumundadır (Alkan 2008).

Türkiye'de orman mühendisliği mesleğinin uzun bir geçmişi olup, ormancılık eğitim ve öğretimi 1857 yılında İstanbul'da kurulan Orman Okulu ile başlamıştır. Günümüzde orman mühendisliği, orman endüstri mühendisliği ve peyzaj mimarlığı lisans programlarıyla, ormancılık eğitim ve öğretimi veren birçok orman fakültesi bulunmaktadır. Orman fakültelerinin orman mühendisliği bölümünden lisans eğitimiyle mezun olmuş kişilere “orman mühendisi” ünvanı verilmektedir. URL-1 (2006)'de orman mühendislerinin gerçekleştireceği görevler tanımlanmıştır. 
Orman kaynaklarının yönetimi, korunması ve geliştirilmesinde orman mühendisleri ile birlikte orman muhafaza memurları da etkin şekilde görevlendirilmiştir. Orman muhafaza memurları, ağırlıklı olarak lise seviyesinde bir eğitime sahip olup, \% 10'u ön lisans mezunu ve \%3,5'i lisans mezunudur (Öztürk 2013). Orman muhafaza memurlarının orman işletme müdürlükleri ile orman işletme şefliklerinde gerçekleştireceği görevler URL-2 (1996)'de belirtilmiştir.

Orman mühendisleri ile yardımcı teknik personel kapsamında değerlendirilen orman muhafaza memurları, ormancılığın biyolojik, teknik, ekonomik, sosyal vb. faaliyetlerini yerine getirmektedir. Bu faaliyetler, genellikle yerleşim yerlerine uzakta, açık arazi şartlarına ve her türlü dış etkiye açık, yüksek enerji tüketimi gerektiren, iş güvenliği açısından yüksek kaza risklerini bünyesinde barındırmaktadır (Yazıcı 1990, OGM 2009).

Günümüz ormancılığında tartışmalar daha çok ormancılık sektörünün amaçları, merkez ve taşra örgütlerinin organizasyonları, ormancılığın daha fazla fonksiyonu dikkate alacak şekilde çok yönlü olarak işletilmesi ve yerel halkın katılımıyla yönetilmesi gibi konularda yoğunlaşmaktadır (Türker vd. 2002). TODAİE (2002)'de orman işletme müdürlüklerinin korumadan üretime, inşaattan silvikültüre, pazarlamadan kadastro-mülkiyet işlemlerine kadar çok farklı alanlarda ve çok fazla çeşitte iş yaptıkları için uygulamada pek çok sorunla karşılaştıkları ve yapmaları gereken ormancılık faaliyetlerine yeterince zaman ayıramadıkları belirtilmiştir. Bu raporda, işletme müdürlüklerinin personel açısından güçlü bir yapıya sahip olması için işletme bünyesinde çeşitli hizmet gruplarında (koruma, üretim, silvikültür, inşaat, pazarlama, mülkiyet ve izin vb.) uzmanlaşmış mühendislerin bulundurulması önerilmiştir.

Kalıpsız (1963) ve Türkmen (1972)'de orman işletme şeflerinin iş miktarının fazla olduğu ve bu işlerin bir kısmının yardımcı personele dağıtılması gerektiği vurgulanmıştır. Anıl ve Çağlar (1976), Yomralığlu (1987), Çağlar (1990) ve Geray (2001)'de yapılan işlerin uzmanlıklara göre ayrılması önerilmiş, Orman Genel Müdürlüğü (OGM) sistemine personel politikası, örgütlenme, işbölümü ve eğitim açısından yeni bir biçim verilmesi gerektiğini vurgulanmıştır. Yurdakul (2003), Yavuz (2007), Şafak (2008) ve Yaman (2010)'de Orman Genel Müdürlüğü personel yönetimi incelenmiş ve orman işletmelerinde çalışma koşulları, iş yoğunluğu, eğitim, personel, yönetim ve yönetsel sorunlar açıklamıştır. Elvan (2005)'de ormanların korunmasında orman muhafaza memurlarının görev ve yetkileri, Öztürk (2013)'de ise orman muhafaza memurlarının sorunları incelenmiştir.

Yukarıdaki çalışmalarda, orman işletme müdürlüklerinde, iş çeşitlerinin belirlenmediği, iş tanımlarının yapılmadığı, orman mühendislerinin iş yükünün fazla olduğu, görev dağılımının uygun olmadığı ve uzmanlık birimlerinin oluşturulmadığı genel olarak vurgulanmaktadır. Şafak vd. (2015)'da Denizli Orman İşletme Müdürlüğünde 2189 adet işin gerçekleştirildiği saptanmış ve bu faaliyetlerin \% 67'sinin orman işletme şefleri, \% 14,1'inin de orman muhafaza memurları tarafından yapıldığı vurgulanmıştır. Nitekim bu faaliyetlerin \% 20'si, orman zararlıları ile mücadele (OZM) şube müdürlüğünün görev alanı ile ilişkilendirilmiştir. Bu kapsamda, Denizli Orman Bölge Müdürlüğüne bağlı Orman Zararlıları ile Mücadele (OZM) Şube Müdürlüğünün çalışma konuları aşağıda belirtilmiştir (URL-3 2018).

a) Ormanların zararlı böcek ve hastalılar ile yasadışı müdahalelere karşı korunması faaliyetlerinin yürütülmesini sağlamak,

b) Karantina tedbirleri ve uygulamalarının yürütülmesini sağlamak,

c) Orman ekosistemlerinin sağlığının izlenmesi ile ilgili iş ve işlemleri yürütmek,

d) Muhafaza ormanlarının ayrılması ve idaresi ile ilgili iş ve işlemleri yürütmek,

e) Orman içi otlak, yaylak ve kışlaklarda otlatmanın planlaması ve takibinin yapılmasını sağlamak,

f) Memurlara verilecek giyimler, ihtiyaç duyulan damga, nakliye tezkeresi ve silahların temini, dağıtımı ve diğer işlemlerinin takibi ile ilgili işlemlerin yürütülmesini sağlamaktır.

Bu makalede, Denizli Orman İşletme Müdürlüğünde görevli orman mühendisi ile orman muhafaza memurlarının OZM şube müdürlüğünün yukarıda tanımlanan çalışma alanına giren konularda gerçekleştirdikleri faaliyetlere verdikleri önem düzeyi ile bu faaliyetlere ayırdıkları zaman miktarının mevsimsel bazda değişip değişmediği araştırılmıştır. Bu değerlendirmeler, OZM'ye yönelik faaliyetlerin dönemsel ve yıllık olarak belirlenmesi, orman mühendisleri ile orman muhafaza memurlarının iş yüklerinin saptanması ve OZM kapsamında önemli ve önemsiz olarak atfedilen faaliyetlerin gözden geçirilmesi açısından önemlidir.

\section{Materyal ve Yöntem}

\subsection{Araştırma Alanı}

Araştırma, Denizli Orman Bölge Müdürlüğüne bağlı Denizli Orman İşletme Müdürlüğünde yürütülmüştür. Denizli Orman İşletme Müdürlüğü, Buldan, Güney, Denizli, Honaz, Kaklık, Kocabaş, Pamukkale, Sarayköy İşletme Şeflikleri, Kadastro Mülkiyet Şefliği ve Ağaçlandırma ve Toprak Muhafaza Şefliği ile hizmet vermektedir.

Denizli Orman İşletme Müdürlüğünün sorumluluğundaki 147127,1 hektar orman alanının \%65'i (95512,2 ha.) verimli, \%35'i (51614,9 ha.) bozuk yapıdadır. Sorumluluk alanı içinde 6 ilçe, 18 kasaba, 110 orman köyü (mahallesi) bulunmaktadır. Köylerin 67'si 31. madde orman köyü, 32'si 32. madde orman köyüdür. Sorumluluğunda 1 adet kent ormanı, 8 adet orman içi dinlenme yeri bulunmaktadır.

Denizli Orman İşletme Müdürlüğünde 79’u memur, 201'i işçi kadrosunda olmak üzere toplam 280 personel görev yapmaktadır. Memur kadrosunda bulunanların 13'ü mühendis, 33'ü orman muhafaza memuru, 2'si avukat, 2'si sayman, 7'si katip, 22'si işletme müdürlüğü bünyesinde diğer görevlerde hizmet yapmaktadır. 
İşçi kadrosunda bulunanların 86'sı şoför (hizmet vasıtası, arazöz, ranger, traktör, su ikmal, greyder, tır, dozer, eksvatör), 57'si yangın işçisi, 58'i ise telsiz, santral, odacı, tamirci, büro elemanı, arazi işçisi vb görevlerdedir.

\subsection{Anket Formunun Tasarlanması ve Uygulanması}

Anket, sistematik bir veri toplama yöntemi olup, veriler daha önceden belirlenmiş sorular yardımıyla toplanmaktadır. İşlerin çok kapsamlı olması, geniş bir coğrafik alanda yapılıyor olması ya da gözlem ve görüşme yöntemi ile bilgi toplanmasının zor olduğu durumlarda anket yönteminden yararlanılmaktadır (Bircan 2005). Anket yöntemi ile insan davranışları, iş performansları, bilgi düzeyleri, tercihler, tutumlar, inançlar, duygular gibi çok farklı türde veri toplamak mümkündür. Bu kapsamda, Denizli Orman İşletme Müdürlüğü’nde, OZM şube müdürlüğü bazında yürütülen işlerin, mevsimlere göre farklılaşıp farklılaşmadığını tespit etmek amacıyla anket yönteminden yararlanılmıştır.

Tablo 1'de sunulan OZM ile ilgili faaliyetler, Şafak vd. (2015)'de Denizli Orman İşletme Müdürlüğünün OZM ile ilgili iş çeşitlerinin gruplandırılması sonucunda elde edilmiştir. Bu faaliyetler ile anket formu şekillendirilmiştir. Anket formu 14 maddelik iki sorudan oluşmaktadır. Birinci soruda Tablo 1'de detayları verilen faaliyetlere verilen önem düzeyinin, ikinci soruda ise bu faaliyetlere ayrılan zaman miktarının belirlenmesi amaçlanmıştır.

Tablo 1: OZM kapsamında yürütülen ormancılık faaliyetleri

\begin{tabular}{|l|l|l|}
\hline No & $\begin{array}{c}\text { Faaliyet } \\
\text { Kodu }\end{array}$ & \multicolumn{1}{|c|}{ Faaliyet } \\
\hline 1 & Faaliyet1 & Koruma ve Orman Suçlarının Tespitine Yönelik Faaliyetler \\
\hline 2 & Faaliyet2 & Adli Arama Faaliyetleri \\
\hline 3 & Faaliyet3 & Müsadereli Orman Emvali, El Koyma ve Suç Aletlerine Yönelik İşler \\
\hline 4 & Faaliyet4 & Otlatma Faaliyetleri (Planlama, İzin ve Koruma İşleri) \\
\hline 5 & Faaliyet5 & Orman Kanununa Aykırı Eylemlerde Tazminat Hesaplaması \\
\hline 6 & Faaliyet6 & Silah ve Mermi Teslimi, Temini, Kaybedilmesi vb. Faaliyetler \\
\hline 7 & Faaliyet7 & Koruma Ekipleri ve Orman Muhafaza Memurları ile İlgili İşler \\
\hline 8 & Faaliyet8 & Zararlılarla Mekanik Mücadele Faaliyetleri \\
\hline 9 & Faaliyet9 & Zararlılarla Biyolojik Mücadele Faaliyetleri \\
\hline 10 & Faaliyet10 & Zararlılarla Kimyasal Mücadele Faaliyetleri \\
\hline 11 & Faaliyet11 & Karantina Tedbirleri ve Uygulamalarının Yürütülmesine Yönelik İşler \\
\hline 12 & Faaliyet12 & Muhafaza Ormanlarının Ayrılması ve İdaresi İle İlgili İş ve İşlemler \\
\hline 13 & Faaliyet13 & $\begin{array}{l}\text { Ormanların Hava Kirliliği Üzerindeki Etkilerinin Değerlendirilmesi ve İzlenmesine Yönelik } \\
\text { Uluslararası İşbirliği Programı (ICP Programı) Kapsamındaki Faaliyetler }\end{array}$ \\
\hline 14 & Faaliyet14 & Koruma ve OZM Konularındaki Eğitim Faaliyetleri \\
\hline
\end{tabular}

Anketlerde OZM faaliyetlerine harcanan zaman yüzdesi, OZM ile ilgili 14 faaliyetin toplamı 100 olacak şekilde, her bir faaliyet için \% cinsinden ayrı ayrı elde edilmiştir. Her bir iş çeşidine verilen önem düzeyinin belirlenmesinde, Şekil 1 'de sunulan dokuz dereceli Likert ölçeğinden yararlanılmıştır.

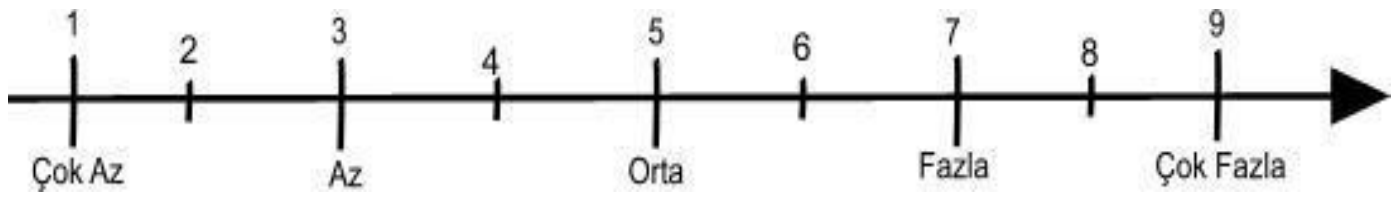

Şekil 1: Dokuz dereceli likert ölçeği

Anketler, sonbahar, kış, ilkbahar ve yaz mevsimlerini dikkate alacak şekilde ayrı ayrı hazırlanmıştır. Anketler, Denizli Orman İşletme Müdürlüğü'nde görevli orman mühendisi ile orman muhafaza memurlarının tamamına mevsiminde uygulanmıştır. Buna göre, sonbahar mevsiminde yapılan ilk grup anketlerini 22 orman muhafaza memuru, 6 orman işletme şefi, 1 müdür yardımcısı olmak üzere toplam 29 personel cevaplandırmıştır. Kış mevsiminde yapılan anketleri 24 orman muhafaza memuru, 6 orman işletme şefi, 1 müdür yardımcısı olmak üzere toplam 31 personel cevaplandırmıştır. İlkbahar mevsiminde yapılan anketleri 23 orman muhafaza memuru, 8 orman işletme şefi olmak üzere toplam 31 personel cevaplandırmıştır. Son olarak yaz mevsiminde yapılan anketleri 23 orman muhafaza memuru, 9 orman işletme şefi olmak üzere toplam 32 personel cevaplandırmıştır. Personelin izinde ve/veya arazide olması mevsimsel olarak anketlerin cevaplanma sayılarında değişikliğe neden olmuştur. Değerlendirmede, orman işletme müdür yardımcıları ile orman işletme şeflerinin görüşleri birleştirilmiş ve orman mühendisi olarak dikkate alınmıştır. 


\subsection{Verilerin Değerlendirilmesinde Kullanılan Yöntemler}

Elde verilerin dağılım biçimi Kolmogrov-Smirnov testiyle, varyansı ise Levene testi ile değerlendirilmiştir (Tablo 2). OZM faaliyetlerine verilen önem düzeyi ile harcanan zaman açısından, istatistikî anlamda farklılığın bulunup bulunmadığı, normal dağılım gösteren ve eşit varyansa sahip olan veriler için tek yönlü varyans analizi (ANOVA) ile normal dağılım göstermeyen veriler için ise Kruskal-Wallis H testi ile incelenmiştir (Tablo 3 ve Tablo 4). Farklılığın bulunması durumunda, hangi kademeler arasında farklığın bulunduğunu test etmek amacıyla t testi ve Mann-Whitney U testlerinden yararlanılmıştır.

Tablo 2: Verilerin dağılım biçimi ve varyans eşitliği

\begin{tabular}{|l|c|c|c|c|c|c|}
\hline \multirow{2}{*}{$\begin{array}{l}\text { Faaliyet } \\
\text { Kodu }\end{array}$} & \multicolumn{3}{|c|}{ Önem Düzeyi } & \multicolumn{3}{c|}{ Zaman Yüzdesi } \\
\cline { 2 - 7 } & $\begin{array}{l}\text { Kolmogrov- } \\
\text { Smirnov Testi } \\
(\mathbf{p})\end{array}$ & Levene (p) & Yöntem & $\begin{array}{l}\text { Kolmogrov- } \\
\text { Smirnov Testi } \\
(\mathbf{p})\end{array}$ & Levene (p) & Yöntem \\
\hline Faaliyet1 & 0,000 & 0,000 & Kruskal & 0,000 & $0,526^{*}$ & Kruskal \\
\hline Faaliyet2 & 0,000 & $0,362^{*}$ & Kruskal & 0,001 & $0,121^{*}$ & Kruskal \\
\hline Faaliyet3 & 0,000 & $0,329^{*}$ & Kruskal & 0,000 & $0,850^{*}$ & Kruskal \\
\hline Faaliyet4 & 0,000 & $0,913^{*}$ & Kruskal & 0,000 & $0,112^{*}$ & Kruskal \\
\hline Faaliyet5 & 0,000 & $0,201^{*}$ & Kruskal & 0,010 & $0,306^{*}$ & Kruskal \\
\hline Faaliyet6 & 0,000 & $0,093^{*}$ & Kruskal & 0,000 & $0,958^{*}$ & Kruskal \\
\hline Faaliyet7 & 0,000 & $0,952^{*}$ & Kruskal & 0,000 & $0,202^{*}$ & Kruskal \\
\hline Faaliyet8 & 0,000 & $0,599^{*}$ & Kruskal & 0,000 & $0,912^{*}$ & Kruskal \\
\hline Faaliyet9 & 0,000 & $0,537^{*}$ & Kruskal & 0,000 & $0,815^{*}$ & Kruskal \\
\hline Faaliyet10 & 0,000 & $0,948^{*}$ & Kruskal & 0,001 & $0,624^{*}$ & Kruskal \\
\hline Faaliyet11 & 0,004 & $0,691^{*}$ & Kruskal & 0,002 & $0,171^{*}$ & Kruskal \\
\hline Faaliyet12 & 0,013 & $0,740^{*}$ & Kruskal & 0,003 & $0,361^{*}$ & Kruskal \\
\hline Faaliyet13 & $0,054^{+}$ & $0,682^{*}$ & ANOVA & 0,001 & $0,995^{*}$ & Kruskal \\
\hline Faaliyet14 & 0,000 & $0,168^{*}$ & Kruskal & 0,000 & $0,204^{*}$ & Kruskal \\
\hline + normal dağı̆llm, ${ }^{*}$ varyans eșitliği & \multicolumn{3}{|l}{} & & \\
\hline
\end{tabular}

Önem düzeyleri bakımından elde edilen verilerde, Tablo 2'de görüldüğü gibi sadece Faaliyet 13'ün (ICP Programı Kapsamındaki Faaliyetler) verileri normal dağılım göstermekte, diğer faaliyetlerin verileri ise normal dağılım göstermemektedir. Aynı kapsamda, zaman yüzdesi bakımından elde edilen verilerin tamamı normal dağılmamaktadır.

Tablo 3 ve Tablo 4'de mevsimsel verilerin dağılım biçimi ve varyans eşitliği incelenmiş, mevsimsel farklılık bulunması durumunda kullanılan yöntem açıklanmıştır. Buna göre, önem ve zaman düzeyine yönelik her iki veri setinde de normal dağılım gösteren ve göstermeyen veriler bulunmaktadır.

Tablo 3: OZM faaliyetlerine verilen önem puanları açısından verilerin dağılım biçimi ve varyans eşitliği

\begin{tabular}{|c|c|c|c|c|c|c|c|c|c|c|c|c|}
\hline \multirow[b]{2}{*}{$\begin{array}{c}\text { Faaliyet } \\
\text { Kodu }\end{array}$} & \multicolumn{3}{|c|}{ Kış } & \multicolumn{3}{|c|}{ İkbahar } & \multicolumn{3}{|c|}{ Sonbahar } & \multicolumn{3}{|c|}{ Yaz } \\
\hline & $\begin{array}{c}\text { Kol- } \\
\text { Smir. } \\
\text { Testi } \\
\text { (p) }\end{array}$ & $\begin{array}{c}\text { Levene } \\
\text { (p) }\end{array}$ & Yöntem & $\begin{array}{c}\text { Kol- } \\
\text { Smir. } \\
\text { Testi } \\
\text { (p) }\end{array}$ & $\begin{array}{c}\text { Levene } \\
\text { (p) }\end{array}$ & Yöntem & $\begin{array}{c}\text { Kol- } \\
\text { Smir. } \\
\text { Testi } \\
\text { (p) }\end{array}$ & $\begin{array}{c}\text { Levene } \\
\text { (p) }\end{array}$ & Yöntem & $\begin{array}{c}\text { Kol- } \\
\text { Smir. } \\
\text { Testi } \\
\text { (p) }\end{array}$ & $\begin{array}{c}\text { Levene } \\
\text { (p) }\end{array}$ & Yöntem \\
\hline Faaliyet1 & 0,000 & $0,769 *$ & Mann & 0,005 & 0,033 & Mann & 0,000 & 0,000 & Mann & $0,052^{+}$ & 0,001 & Mann \\
\hline Faaliyet2 & 0,032 & 0,000 & Mann & 0,015 & 0,000 & Mann & 0,042 & 0,000 & Mann & 0,025 & 0,001 & Mann \\
\hline Faaliyet3 & $0,125^{+}$ & \begin{tabular}{|l}
$0,078^{*}$ \\
\end{tabular} & T Testi & \begin{tabular}{|l}
$0,080^{+}$ \\
\end{tabular} & 0,019 & Mann & 0,043 & 0,005 & Mann & $0,108^{+}$ & 0,016 & Mann \\
\hline Faaliyet 4 & 0,019 & $0,070^{*}$ & Mann & $0,204^{+}$ & $0,290 *$ & T Testi & 0,028 & $0,168 *$ & Mann & $0,321^{+}$ & $0,263 *$ & T Testi \\
\hline Faaliyet5 & 0,003 & 0,834* & Mann & $0,053^{+}$ & $0,724 *$ & T Testi & 0,015 & $0,227 *$ & Mann & 0,012 & $0,105 *$ & Mann \\
\hline Faaliyet6 & $0,113^{+}$ & $0,282^{*}$ & T Testi & $0,064^{+}$ & 0,013 & Mann & 0,029 & $0,589 *$ & Mann & 0,015 & 0,046 & Mann \\
\hline Faaliyet7 & $0,076^{+}$ & $0,547^{*}$ & T Testi & 0,049 & $0,111^{*}$ & Mann & 0,020 & $0,313^{*}$ & Mann & $0,139^{+}$ & $0,877 *$ & T Testi \\
\hline Faaliyet8 & 0,010 & 0,707* & Mann & $0,206^{+}$ & 0,014 & Mann & 0,023 & 0,021 & Mann & $0,068^{+}$ & $0,137 *$ & T Testi \\
\hline Faaliyet9 & 0,017 & $0,221 *$ & Mann & $0,255^{+}$ & 0,007 & Mann & 0,007 & 0,000 & Mann & $0,246^{+}$ & $0,160 *$ & T Testi \\
\hline Faaliyet10 & $0,194^{+}$ & \begin{tabular}{|l}
$0,134^{*}$ \\
\end{tabular} & T Testi & $0,296^{+}$ & 0,097* & T Testi & 0,020 & 0,078* & Mann & $0,140^{+}$ & $0,052 *$ & T Testi \\
\hline Faaliyet11 & $0,493^{+}$ & $0,296^{*}$ & T Testi & $0,307^{+}$ & $0,141^{*}$ & T Testi & $0,057^{+}$ & $0,078^{*}$ & T Testi & $0,317^{+}$ & $0,116^{*}$ & T Testi \\
\hline Faaliyet12 & $0,425^{+}$ & 0,027 & Mann & $0,629^{+}$ & 0,009 & Mann & 0,044 & 0,004 & Mann & $0,198^{+}$ & 0,017 & Mann \\
\hline Faaliyet13 & $0,488^{+}$ & 0,010 & Mann & $0,551^{+}$ & $0,171^{*}$ & T Testi & $0,230^{+}$ & $0,092^{*}$ & T Testi & $0,342^{+}$ & $0,063^{*}$ & $\mathrm{~T}$ Testi \\
\hline Faaliyet14 & $0,064^{+}$ & 0,013 & Mann & $0,309^{+}$ & $0,629^{*}$ & T Testi & $0,126^{+}$ & 0,011 & Mann & $0,344^{+}$ & $0,604 *$ & T Testi \\
\hline
\end{tabular}


Tablo 4: OZM faaliyetlerine ayrılan zaman yüzdesi açısından verilerin dağılım biçimi ve varyans eşitliği

\begin{tabular}{|c|c|c|c|c|c|c|c|c|c|c|c|c|}
\hline \multirow[b]{2}{*}{$\begin{array}{l}\text { Faaliyet } \\
\text { Kodu }\end{array}$} & \multicolumn{3}{|c|}{ Kış } & \multicolumn{3}{|c|}{ İlkbahar } & \multicolumn{3}{|c|}{ Sonbahar } & \multicolumn{3}{|c|}{ Yaz } \\
\hline & $\begin{array}{c}\text { Kol- } \\
\text { Smir. } \\
\text { Testi } \\
\text { (p) }\end{array}$ & $\begin{array}{l}\text { Levene } \\
\text { (p) }\end{array}$ & Yöntem & $\begin{array}{l}\text { Kol- } \\
\text { Smir. } \\
\text { Testi } \\
\text { (p) }\end{array}$ & $\begin{array}{l}\text { Levene } \\
\text { (p) }\end{array}$ & Yöntem & $\begin{array}{c}\text { Kol- } \\
\text { Smir. } \\
\text { Testi } \\
\text { (p) }\end{array}$ & $\begin{array}{c}\text { Levene } \\
\text { (p) }\end{array}$ & Yöntem & $\begin{array}{c}\text { Kol- } \\
\text { Smir. } \\
\text { Testi } \\
\text { (p) }\end{array}$ & $\begin{array}{l}\text { Levene } \\
\text { (p) }\end{array}$ & Yöntem \\
\hline Faaliyet1 & 0,029 & 0,000 & Mann & 0,024 & $0,705^{*}$ & Mann & $0,086^{+}$ & 0,000 & Mann & $0,072^{+}$ & $0,853 *$ & T Testi \\
\hline Faaliyet2 & $0,353^{+}$ & $0,778^{*}$ & T Testi & $0,238^{+}$ & $0,239 *$ & T Testi & 0,036 & $0,823^{*}$ & Mann & $0,600^{+}$ & $0,059 *$ & T Testi \\
\hline Faaliyet3 & $0,394^{+}$ & $0,206^{*}$ & T Testi & 0,009 & 0,039 & Mann & $0,242^{+}$ & $0,857^{*}$ & T Testi & $0,059^{+}$ & 0,004 & Mann \\
\hline Faaliyet4 & $0,172^{+}$ & $0,118^{*}$ & T Testi & 0,046 & $0,192 *$ & Mann & 0,013 & $0,490 *$ & Mann & $0,136^{+}$ & 0,005 & Mann \\
\hline Faaliyet5 & $0,480^{+}$ & $0,069^{*}$ & T Testi & $0,126^{+}$ & $0,079 *$ & T Testi & $0,487^{+}$ & 0,040 & Mann & $0,320^{+}$ & $0,053^{*}$ & T Testi \\
\hline Faaliyet6 & $0,151^{+}$ & $0,157^{*}$ & T Testi & $0,098^{+}$ & $0,331 *$ & T Testi & 0,008 & $0,283^{*}$ & Mann & $0,132^{+}$ & $0,706^{*}$ & T Testi \\
\hline Faaliyet7 & $0,099^{+}$ & $0,330^{*}$ & T Testi & 0,003 & $0,296^{*}$ & Mann & 0,009 & $0,895 *$ & Mann & 0,032 & $0,629 *$ & Mann \\
\hline Faaliyet8 & $0,056^{+}$ & $0,055^{*}$ & T Testi & 0,036 & $0,863^{*}$ & Mann & 0,018 & $0,175^{*}$ & Mann & $0,286^{+}$ & $0,093 *$ & T Testi \\
\hline Faaliyet9 & $0,115^{+}$ & $0,465^{*}$ & T Testi & $0,165^{+}$ & $0,297 *$ & T Testi & 0,013 & $0,440 *$ & Mann & $0,097^{+}$ & $0,277 *$ & T Testi \\
\hline Faaliyet10 & $0,331^{+}$ & $0,332 *$ & T Testi & $0,198^{+}$ & $0,928^{*}$ & T Testi & 0,019 & $0,698^{*}$ & Mann & $0,125^{+}$ & $0,414^{*}$ & T Testi \\
\hline Faaliyet11 & $0,407^{+}$ & $0,114^{*}$ & T Testi & $0,186^{+}$ & $0,111 *$ & T Testi & $0,225^{+}$ & $0,089^{*}$ & T Testi & 0,049 & $0,902 *$ & Mann \\
\hline Faaliyet12 & $0,203^{+}$ & 0,835* & T Testi & $0,425^{+}$ & $0,114 *$ & T Testi & $0,253^{+}$ & 0,042 & Mann & $0,295^{+}$ & $0,566^{*}$ & T Testi \\
\hline Faaliyet13 & $0,170^{+}$ & $0,511^{*}$ & T Testi & $0,452^{+}$ & $0,577 *$ & T Testi & $0,220^{+}$ & $0,208^{*}$ & T Testi & $0,357^{+}$ & $0,570^{*}$ & T Testi \\
\hline Faaliyet14 & $0,547^{+}$ & $0,121^{*}$ & T Testi & 0,028 & $0,086^{*}$ & Mann & $0,059^{+}$ & 0,026 & Mann & $0,375^{+}$ & 0,040 & Mann \\
\hline
\end{tabular}

\section{Bulgular}

\subsection{OZM Faaliyetlerine Verilen Önem ve Ayrılan Zaman Düzeyinin Dağılımı}

Denizli Orman İşletme Müdürlüğü’nde yürütülen işlerde mevsimsel bazda oluşan değişiklikler, faaliyetlere/işlere verilen önem ve bunlara ayrılan zaman yüzdesi bu başlıkta araştırılmıştır. Tablo 5'de OZM kapsamında yürütülen 14 ormancılık faaliyeti genel olarak değerlendirildiğinde, 8,3 puan ile koruma ve orman suçlarının tespitine yönelik faaliyetlere (Faaliyet 1) en fazla önem verilmektedir. İkinci sırada 7,5 puan müsadereli orman emvali, el koyma ve suç aletlerine yönelik işler (Faaliyet 3); otlatma faaliyetleri (Faaliyet 4) ile koruma ekipleri ve orman muhafaza memurları ile ilgili işler (Faaliyet 7) yer almaktadır. ICP programı kapsamındaki faaliyetlere (Faaliyet 13) ise 5 puan ile en az önem verilmektedir.

Tablo 5: OZM kapsamında yürütülen ormancılık faaliyetlerine verilen önem puanları

\begin{tabular}{|c|c|c|c|c|c|c|c|c|c|c|c|c|c|c|c|c|}
\hline \multirow{2}{*}{$\begin{array}{c}\text { Faaliyet } \\
\text { Kodu }\end{array}$} & \multicolumn{4}{|c|}{ Muhafaza Memuru } & \multicolumn{4}{|c|}{ Orman İșetme Şefi } & \multicolumn{4}{c|}{ Genel Ortalama } \\
\hline & Sbah & Kış & İbah & Yaz & Ort & Sbah & Kış & İbah & Yaz & Ort & Sbah & Kış & İbah & Yaz & Ort \\
\hline Faaliyet1 & 8,7 & 8,8 & 8,1 & 7,8 & 8,3 & 8,7 & 8,7 & 7,7 & 7,3 & 8,0 & 8,7 & 8,7 & 8,0 & 7,6 & $\mathbf{8 , 3}$ \\
\hline Faaliyet2 & 8,0 & 7,9 & 7,5 & 7,4 & 7,7 & 6,4 & 6,4 & 5,8 & 5,4 & 6,0 & 7,6 & 7,5 & 7,1 & 6,9 & $\mathbf{7 , 3}$ \\
\hline Faaliyet3 & 8,0 & 7,8 & 7,8 & 7,2 & 7,7 & 7,4 & 7,3 & 7,2 & 6,6 & 7,1 & 7,9 & 7,7 & 7,6 & 7,0 & $\mathbf{7 , 5}$ \\
\hline Faaliyet4 & 7,9 & 8,0 & 7,2 & 7,4 & 7,6 & 7,3 & 7,3 & 7,3 & 7,0 & 7,2 & 7,8 & 7,8 & 7,2 & 7,3 & $\mathbf{7 , 5}$ \\
\hline Faaliyet5 & 7,3 & 7,3 & 5,7 & 7,0 & 6,8 & 7,3 & 7,3 & 6,8 & 6,5 & 6,9 & 7,3 & 7,3 & 6,0 & 6,9 & $\mathbf{6 , 8}$ \\
\hline Faaliyet6 & 7,5 & 7,4 & 7,1 & 7,0 & 7,2 & 7,1 & 6,9 & 5,7 & 5,4 & 6,2 & 7,4 & 7,3 & 6,7 & 6,5 & $\mathbf{7 , 0}$ \\
\hline Faaliyet7 & 7,5 & 7,4 & 7,5 & 7,2 & 7,4 & 8,0 & 8,0 & 7,7 & 7,5 & 7,8 & 7,6 & 7,6 & 7,5 & 7,3 & $\mathbf{7 , 5}$ \\
\hline Faaliyet8 & 7,0 & 6,2 & 5,9 & 6,3 & 6,3 & 7,3 & 7,1 & 6,3 & 6,1 & 6,7 & 7,0 & 6,4 & 6,0 & 6,2 & $\mathbf{6 , 4}$ \\
\hline Faaliyet9 & 7,1 & 6,5 & 5,4 & 5,9 & 6,2 & 6,4 & 6,3 & 6,2 & 6,0 & 6,2 & 6,9 & 6,4 & 5,6 & 5,9 & $\mathbf{6 , 2}$ \\
\hline Faaliyet10 & 6,0 & 5,8 & 5,0 & 6,0 & 5,7 & 6,4 & 5,1 & 4,2 & 3,9 & 4,8 & 6,1 & 5,6 & 4,8 & 5,5 & $\mathbf{5 , 5}$ \\
\hline Faaliyet11 & 5,9 & 5,0 & 4,9 & 5,7 & 5,3 & 4,7 & 4,1 & 4,2 & 3,9 & 4,2 & 5,6 & 4,8 & 4,7 & 5,2 & $\mathbf{5 , 1}$ \\
\hline Faaliyet12 & 6,2 & 5,3 & 6,4 & 6,1 & 6,0 & 4,7 & 4,6 & 4,3 & 3,9 & 4,4 & 5,9 & 5,1 & 5,8 & 5,5 & $\mathbf{5 , 6}$ \\
\hline Faaliyet13 & 5,3 & 5,6 & 4,6 & 5,3 & 5,2 & 4,7 & 4,6 & 4,6 & 4,1 & 4,5 & 5,1 & 5,4 & 4,6 & 5,0 & $\mathbf{5 , 0}$ \\
\hline Faaliyet14 & 6,4 & 6,4 & 5,8 & 6,7 & 6,3 & 4,7 & 5,7 & 6,7 & 6,4 & 5,9 & 6,0 & 6,3 & 6,0 & 6,6 & $\mathbf{6 , 2}$ \\
\hline
\end{tabular}

Mevsimler bazında önem puanları birbirlerine göre değişken olup bütün mevsimlerde en fazla önem koruma ve orman suçlarının tespitine yönelik faaliyetlere (Faaliyet 1) verilmektedir. Orman muhafaza memurları tarafından yapılan değerlendirmelerde dokuzlu likert ölçeğine göre orta düzeyin ( 5 puanın) altında öneme sahip faaliyet bulunmazken orman işletme şefleri tarafından yapılan değerlendirmelerde orta düzeyin altında dört faaliyet (zararlılarla kimyasal mücadele faaliyetleri (Faaliyet 10), karantina tedbirleri ve uygulamalarının yürütülmesine yönelik işler (Faaliyet 11), (muhafaza ormanlarının ayrılması ve idaresi ile ilgili iş ve işlemler (Faaliyet 12) ile ICP programı kapsamındaki faaliyetler (Faaliyet 13) bulunmaktadır.

Tablo 6'da OZM kapsamında yürütülen 14 ormancılık faaliyetine ayrılan zamanlar değerlendirilmiş olup mevsimsel bazda en fazla zaman \%17,7 ile koruma ve orman suçlarının tespitine yönelik faaliyetlere (Faaliyet 1) ayrılmaktadır. 
İkinci sırada \%10,3 ile koruma ekipleri ve orman muhafaza memurları ile ilgili işler (Faaliyet 7), üçüncü sırada ise \%9,1 ile müsadereli orman emvali, el koyma ve suç aletlerine yönelik işler (Faaliyet 3) en fazla zamanı almaktadır. En az zaman ise \%3,5 ile karantina tedbirleri ve uygulamalarının yürütülmesini sağlamaya yönelik faaliyetlere (Faaliyet 11) ayrilmaktadir.

Tablo 6: OZM kapsamında yürütülen ormancılık faaliyetlerine ayrılan zaman

\begin{tabular}{|c|c|c|c|c|c|c|c|c|c|c|c|c|c|c|c|}
\hline \multirow{2}{*}{$\begin{array}{c}\text { Faaliyet } \\
\text { Kodu }\end{array}$} & \multicolumn{5}{|c|}{ Muhafaza Memuru } & \multicolumn{5}{|c|}{ Orman İşletme Şefi } & \multicolumn{5}{|c|}{ Genel Ortalama } \\
\hline & Sbah & Kış & İbah & Yaz & Ort & Sbah & Kış & İbah & Yaz & Ort & Sbah & Kış & İbah & Yaz & Ort \\
\hline Faaliyet1 & 13,2 & 11,9 & 18,1 & 19,7 & 15,5 & 25,9 & 25,7 & 22,6 & 22,1 & 23,9 & 16,3 & 15,0 & 19,4 & 20,4 & 17,7 \\
\hline Faaliyet2 & 8,6 & 9,4 & 9,8 & 8,2 & 9,0 & 4,4 & 5,1 & 7,2 & 7,3 & 6,2 & 7,6 & 8,5 & 9,0 & 8,0 & 8,3 \\
\hline Faaliyet3 & 10,1 & 9,6 & 9,3 & 7,1 & 9,1 & 6,6 & 8,0 & 10,8 & 10,6 & 9,2 & 9,3 & 9,3 & 9,7 & 8,1 & 9,1 \\
\hline Faaliyet4 & 8,4 & 9,0 & 7,4 & 8,2 & 8,3 & 8,6 & 8,1 & 7,7 & 7,0 & 7,8 & 8,4 & 8,8 & 7,5 & 7,9 & 8,2 \\
\hline Faaliyet5 & 6,5 & 5,8 & 4,4 & 5,2 & 5,5 & 11,0 & 10,7 & 7,9 & 8,5 & 9,4 & 7,6 & 6,9 & 5,5 & 6,1 & 6,5 \\
\hline Faaliyet6 & 6,5 & 8,0 & 6,5 & 6,2 & 6,9 & 6,1 & 6,3 & 4,1 & 3,2 & 4,8 & 6,5 & 7,6 & 5,8 & 5,4 & 6,3 \\
\hline Faaliyet7 & 10,3 & 11,5 & 7,7 & 9,6 & 9,8 & 10,6 & 12,1 & 10,9 & 12,8 & 11,6 & 10,3 & 11,6 & 8,6 & 10,5 & 10,3 \\
\hline Faaliyet8 & 6,0 & 5,0 & 5,5 & 5,2 & 5,4 & 6,4 & 6,7 & 4,9 & 5,1 & 5,7 & 6,1 & 5,4 & 5,3 & 5,2 & 5,5 \\
\hline Faaliyet9 & 6,3 & 5,5 & 4,1 & 5,3 & 5,3 & 5,0 & 3,9 & 3,9 & 3,4 & 4,0 & 5,9 & 5,2 & 4,1 & 4,8 & 5,0 \\
\hline Faaliyet10 & 4,0 & 4,7 & 4,5 & 4,3 & 4,4 & 3,0 & 2,2 & 2,2 & 1,4 & 2,2 & 3,8 & 4,1 & 3,8 & 3,4 & 3,8 \\
\hline Faaliyet11 & 3,4 & 5,0 & 4,5 & 3,6 & 4,1 & 1,4 & 1,6 & 2,1 & 1,5 & 1,7 & 2,9 & 4,2 & 3,8 & 3,0 & 3,5 \\
\hline Faaliyet12 & 4,9 & 4,4 & 6,9 & 5,1 & 5,3 & 1,4 & 2,3 & 2,4 & 1,9 & 2,0 & 4,1 & 3,9 & 5,6 & 4,2 & 4,4 \\
\hline Faaliyet13 & 4,0 & 4,3 & 4,4 & 4,4 & 4,3 & 1,6 & 1,7 & 2,3 & 2,4 & 2,0 & 3,4 & 3,7 & 3,8 & 3,8 & 3,7 \\
\hline Faaliyet14 & 7,8 & 5,9 & 6,9 & 7,9 & 7,1 & 8,0 & 5,6 & 11,0 & 12,8 & 9,5 & 7,8 & 5,8 & 8,1 & 9,2 & 7,7 \\
\hline
\end{tabular}

\subsection{OZM Faaliyetlerine Verilen Önem ve Ayrılan Zaman Açısından Mevsimsel Farklılık Durumu}

OZM kapsamında yürütülen ormancılık faaliyetlerine verilen önem düzeyi bakımından farklılık olup olmadığı öncelikle dört mevsim için Kruskal-Wallis H. Testi ile Faaliyet 13 için ise ANOVA ile değerlendirilmiştir (Tablo 7). Tablo 7'ye göre Faaliyet 1 (koruma ve orman suçlarının tespitine yönelik faaliyetler) ile Faaliyet 5 (orman kanununa aykırı eylemlerde tazminat hesaplaması)'in yerine getirilmesinde mevsimsel düzeyde farklılık bulunmaktadır. Diğer 12 faaliyet için ise mevsimler arasında anlamlı düzeyde farklılık bulunmamaktadır. Bu farklılığın nedeni, Mann-Whitney U testi ile araştırılmıştır. Buna göre, Faaliyet 1 ve Faaliyet 5 'in dışındaki diğer bütün faaliyetlerde mevsimsel düzeyde farklılık bulunmamakta olup bu durum OZM faaliyetlerinin genelde mevsimlere göre farklılaşmadığını göstermektedir. Faaliyet 1 (koruma ve orman suçlarının tespitine yönelik faaliyetler)'e verilen önem düzeyi bakımından kış ile ilkbahar ve yaz mevsimlerinde $\alpha=0,05$ düzeyinde ve sonbahar ile ilkbahar ve yaz mevsimlerinde $\alpha=0,05$ düzeyinde farklılık bulunmuştur. Faaliyet 5 (orman kanununa aykırı eylemlerde tazminat hesaplaması)'e verilen önem düzeyi bakımından ilkbahar ile kış ve sonbahar mevsimlerinde $\alpha=0,05$ düzeyinde farkl1lık bulunmuştur.

Tablo 7: Faaliyetlerin önem düzeyi açısından mevsimsel farklıı̆ı

\begin{tabular}{|c|c|c|c|c|c|c|c|c|}
\hline \multirow{3}{*}{$\begin{array}{c}\text { Faaliyet } \\
\text { Kodu }\end{array}$} & \multicolumn{8}{|c|}{ Önem Düzeyi } \\
\hline & \multicolumn{2}{|c|}{ Yöntem } & \multicolumn{6}{|c|}{ Mann-Whitney U Testi (p) } \\
\hline & Yöntem & $\mathbf{p}$ & Kış-İlk & Kış-Son & Kış-Yaz & İlk-Son & İlk-Yaz & Son-Yaz \\
\hline Faaliyet1 & Kruskal & $0,000^{*}$ & $0,018^{*}$ & 0,523 & $0,001^{*}$ & $0,005^{*}$ & 0,339 & $0,000^{*}$ \\
\hline Faaliyet2 & Kruskal & 0,493 & - & - & - & - & - & - \\
\hline Faaliyet3 & Kruskal & 0,269 & - & - & - & - & - & - \\
\hline Faaliyet4 & Kruskal & 0,267 & - & - & - & - & - & - \\
\hline Faaliyet5 & Kruskal & $0,018^{*}$ & $0,011^{*}$ & 0,512 & 0,058 & $0,018^{*}$ & 0,233 & 0,111 \\
\hline Faaliyet6 & Kruskal & 0,687 & - & - & - & - & - & - \\
\hline Faaliyet7 & Kruskal & 0,981 & - & - & - & - & - & - \\
\hline Faaliyet8 & Kruskal & 0,385 & - & - & - & - & - & - \\
\hline Faaliyet9 & Kruskal & 0,067 & - & - & - & - & - & - \\
\hline Faaliyet10 & Kruskal & 0,254 & - & - & - & - & - & - \\
\hline Faaliyet11 & Kruskal & 0,469 & - & - & - & - & - & - \\
\hline Faaliyet12 & Kruskal & 0,664 & - & - & - & - & - & - \\
\hline Faaliyet13 & ANOVA & 0,757 & - & - & - & - & - & - \\
\hline Faaliyet14 & Kruskal & 0,944 & - & - & - & - & - & - \\
\hline
\end{tabular}

OZM kapsamında yürütülen ormancılık faaliyetlerine ayrılan zaman yüzdesi bakımından farklılık olup olmadığı öncelikle dört mevsim için Kruskal-Wallis H. Testi ile değerlendirilmiştir (Tablo 8). Kruskal-Wallis H. Testi sonucuna göre 14 OZM faaliyetine ayrılan zaman düzeyi açısından mevsimsel düzeyde farklılık bulunmamaktadır. 
Tablo 8: Faaliyetlere verilen zaman yüzdesi açısından mevsimsel farklıık

\begin{tabular}{|l|l|c|}
\hline Faaliyet Kodu & \multicolumn{1}{|c|}{ Faaliyet } & Kuruskal (p) \\
\hline Faaliyet1 & Koruma ve Orman Suçlarının Tespitine Yönelik Faaliyetler & 0,080 \\
\hline Faaliyet2 & Adli Arama Faaliyetleri & 0,754 \\
\hline Faaliyet3 & Müsadereli Orman Emvali, El Koyma ve Suç Aletlerine Yönelik İşler & 0,434 \\
\hline Faaliyet4 & Otlatma Faaliyetleri (Planlama, İzin ve Koruma İşleri) & 0,264 \\
\hline Faaliyet5 & Orman Kanununa Aykırı Eylemlerde Tazminat Hesaplaması & 0,433 \\
\hline Faaliyet6 & Silah ve Mermi Teslimi, Temini, Kaybedilmesi vb. Faaliyetler & 0,192 \\
\hline Faaliyet7 & Koruma Ekipleri ve Orman Muhafaza Memurları ile İlgili İşler & 0,509 \\
\hline Faaliyet8 & Zararlılarla Mekanik Mücadele Faaliyetleri & 0,615 \\
\hline Faaliyet9 & Zararlılarla Biyolojik Mücadele Faaliyetleri & 0,224 \\
\hline Faaliyet10 & Zararlılarla Kimyasal Mücadele Faaliyetleri & 0,979 \\
\hline Faaliyet11 & Karantina Tedbirleri ve Uygulamalarının Yürütülmesine Yönelik İşler & 0,647 \\
\hline Faaliyet12 & Muhafaza Ormanlarının Ayrılması ve İdaresi İle İlgili İş ve İşlemler & 0,589 \\
\hline Faaliyet13 & ICP Programı Kapsamındaki Faaliyetler & 0,971 \\
\hline Faaliyet14 & Koruma ve OZM Konularındaki Ĕgitim Faaliyetleri & 0,418 \\
\hline
\end{tabular}

\subsection{OZM Faaliyetlerine Verilen Önem ve Ayrılan Zamanın Orman Mühendisleri ile Orman Muhafaza Memurları Açısından Farklılık Durumu}

Mevsimsel bazda orman zararlılarıyla mücadele kapsamında yürütülen ormancılık faaliyetlerine verilen önem bakımından orman mühendisleri ile orman muhafaza memurları arasında farklılık olup olmadığı t testi veya MannWhitney U testi ile araştırılmış olup sonuçlar Tablo 9'da verilmiştir. Tablo 9'dan da görüldüğü gibi hem t testi ile hem de Mann-Whitney U testi ile elde edilen sonuçların tamamında, faaliyetlere verilen önem düzeyi bakımından orman mühendisleri ile orman muhafaza memurları arasında mevsimsel düzeyde farklılık bulunmamaktadır.

Tablo 9: Mevsimsel bazda OZM kapsamında yürütülen ormancılık faaliyetlerine verilen önem açısından orman mühendisleri ile orman muhafaza memurları arasındaki farklılı durumu

\begin{tabular}{|l|c|c|c|c|c|c|c|c|}
\hline \multirow{2}{*}{ Faaliyet Kodu } & \multicolumn{2}{|c|}{ Kiș } & \multicolumn{2}{c|}{ Ilkbahar } & \multicolumn{2}{c|}{ Sonbahar } & \multicolumn{2}{c|}{ Yaz } \\
\cline { 2 - 9 } & Yöntem & $\mathbf{p}$ & Yöntem & $\mathbf{p}$ & Yöntem & $\mathbf{p}$ & Yöntem & p \\
\hline Faaliyet1 & Mann & 0,910 & Mann & 0,871 & Mann & 0,096 & Mann & 0,843 \\
\hline Faaliyet2 & Mann & 0,791 & Mann & 0,633 & Mann & 0,439 & Mann & 0,454 \\
\hline Faaliyet3 & T Testi & 0,505 & Mann & 0,428 & Mann & 0,685 & Mann & 0,904 \\
\hline Faaliyet4 & Mann & 0,936 & T Testi & 0,809 & Mann & 0,839 & T Testi & 0,633 \\
\hline Faaliyet5 & Mann & 0,911 & T Testi & 0,541 & Mann & 0,805 & Mann & 0,961 \\
\hline Faaliyet6 & T Testi & 0,567 & Mann & 0,281 & Mann & 0,859 & Mann & 0,467 \\
\hline Faaliyet7 & T Testi & 0,437 & Mann & 0,965 & Mann & 0,375 & T Testi & 0,796 \\
\hline Faaliyet8 & Mann & 0,184 & Mann & 0,767 & Mann & 0,808 & T Testi & 0,929 \\
\hline Faaliyet9 & Mann & 0,670 & Mann & 0,656 & Mann & 0,732 & T Testi & 0,871 \\
\hline Faaliyet10 & T Testi & 0,655 & T Testi & 0,504 & Mann & 0,827 & T Testi & 0,103 \\
\hline Faaliyet11 & T Testi & 0,576 & T Testi & 0,464 & T Testi & 0,160 & T Testi & 0,162 \\
\hline Faaliyet12 & Mann & 0,729 & Mann & 0,071 & Mann & 0,103 & Mann & 0,166 \\
\hline Faaliyet13 & Mann & 0,620 & T Testi & 0,785 & T Testi & 0,505 & T Testi & 0,340 \\
\hline Faaliyet14 & Mann & 0,821 & T Testi & 0,569 & Mann & 0,185 & T Testi & 0,813 \\
\hline
\end{tabular}

Mevsimsel bazda orman zararlılarıyla mücadele kapsamında yürütülen ormancılık faaliyetlerine ayrılan zaman yüzdesi bakımından orman mühendisleri ile orman muhafaza memurları arasında farklılık olup olmadığı t testi veya Mann-Whitney U testi ile araştırılmış olup sonuçlar Tablo 10’da verilmiştir. 
Tablo 10: Mevsimsel bazda OZM kapsamında yürütülen ormancılık faaliyetlerine ayrılan zaman açısından orman mühendisleri ile orman muhafaza memurları arasındaki farkııık durumu

\begin{tabular}{|l|c|c|c|c|c|c|c|c|}
\hline \multirow{2}{*}{$\begin{array}{l}\text { Faaliyet } \\
\text { Kodu }\end{array}$} & \multicolumn{2}{|c|}{ Kiș } & \multicolumn{2}{c|}{ İlkbahar } & \multicolumn{2}{c|}{ Sonbahar } & \multicolumn{2}{c|}{ Yaz } \\
\cline { 2 - 8 } & Yöntem & p & Yöntem & p & Yöntem & p & Yöntem & p \\
\hline Faaliyet1 & Mann & 0,232 & Mann & 0,496 & Mann & 0,197 & Mann & 0,486 \\
\hline Faaliyet2 & Mann & $0,019^{*}$ & Mann & 0,202 & Mann & $0,019^{*}$ & Mann & 0,228 \\
\hline Faaliyet3 & T Testi & 0,372 & Mann & 0,921 & Mann & 0,173 & Mann & 0,399 \\
\hline Faaliyet4 & Mann & 0,959 & T Testi & 0,950 & Mann & 0,572 & Mann & 0,131 \\
\hline Faaliyet5 & Mann & 0,123 & T Testi & $0,016^{*}$ & Mann & 0,146 & Mann & 0,135 \\
\hline Faaliyet6 & T Testi & 0,339 & Mann & 0,264 & Mann & 0,196 & Mann & $0,045^{*}$ \\
\hline Faaliyet7 & T Testi & 0,847 & Mann & 0,160 & Mann & 0,672 & Mann & 0,235 \\
\hline Faaliyet8 & Mann & 0,436 & Mann & 0,715 & Mann & 0,866 & Mann & 0,745 \\
\hline Faaliyet9 & Mann & 0,167 & Mann & 0,770 & Mann & 0,217 & Mann & 0,098 \\
\hline Faaliyet1 & T Testi & 0,101 & T Testi & 0,112 & Mann & 0,477 & Mann & $0,008^{*}$ \\
\hline Faaliyet1 & T Testi & $0,025^{*}$ & T Testi & $0,033^{*}$ & T Testi & 0,093 & T Testi & $0,042^{*}$ \\
\hline Faaliyet1 & Mann & 0,123 & Mann & $0,011^{*}$ & Mann & 0,053 & Mann & $0,012^{*}$ \\
\hline Faaliyet1 & Mann & 0,073 & T Testi & 0,078 & T Testi & 0,072 & T Testi & 0,141 \\
\hline Faaliyet1 & Mann & 0,438 & T Testi & 0,232 & Mann & 0,450 & Mann & 0,453 \\
\hline
\end{tabular}

*0,05 düzeyinde farklıdır

Tablo 10’da görüldüğü gibi OZM ile ilgili 14 faaliyetin altısında (Faaliyet 2, 5, 6, 10, 11, 12) mevsimsel düzeyde farklılık bulunmakta, diğerlerinde mevsimsel farklılık bulunmamaktadır. Buna göre,

i) Adli arama faaliyetlerine (Faaliyet 2) yönelik çalışmalara ayrılan zaman yüzdesi bakımından orman mühendisleri ile orman muhafaza memurları arasında kıș ve sonbahar mevsiminde farklılık bulunmaktadır.

ii) Orman kanununa aykırı eylemlerde tazminat hesaplamasına (Faaliyet 5) yönelik çalışmalara ayrılan zaman yüzdesi bakımından orman mühendisleri ile orman muhafaza memurları arasında ilkbahar mevsiminde farklılık bulunmaktadır.

iii) Silah ve mermi teslimi, temini, kaybedilmesi vb. faaliyetlere (Faaliyet 6) ile zararlılarla kimyasal mücadele faaliyetlerine (Faaliyet 10) yönelik çalışmalara ayrılan zaman yüzdesi bakımından orman mühendisleri ile orman muhafaza memurları arasında yaz mevsiminde farklılık bulunmaktadır.

iv) Karantina tedbirleri ve uygulamalarının yürütülmesine yönelik işlere (Faaliyet 11) ayrılan zaman yüzdesi bakımından orman mühendisleri ile orman muhafaza memurları arasında kış, ilkbahar ve yaz mevsiminde farklılık bulunmaktadır.

v) Muhafaza ormanlarının ayrılması ve idaresi ile ilgili iş ve işlemlere (Faaliyet 12) ayrılan zaman yüzdesi bakımından orman mühendisleri ile orman muhafaza memurları arasında ilkbahar ve yaz mevsiminde farklılık bulunmaktadır.

\section{Sonuç ve Tartışma}

Orman işletme müdürlüklerinde, OZM konusunda gerçekleştirilen ormancılık faaliyetlerinin yıllık ve dönemler halinde belirlenmesine yönelik bu makale ile elde edilen sonuçlar, sürdürülebilir orman yönetimi açısından önemlidir. $\mathrm{Bu}$ araştırma sonucunda, her bir OZM faaliyeti açısından yüksek veya düşük önem atfedilen faaliyetler ile çok veya az zaman harcanan faaliyetler mevsimsel olarak saptanmıştır.

Araştırma sonuçları, aynı zamanda, OGM'nin OZM ile ilgili gerçekleştirilmesini istediği faaliyetleri taşra teşkilatının (Denizli Orman İşletme Müdürlüğünün) ne ölçüde önemsediğini de göstermektedir. Üst yönetim (OGM) tarafından önemsenen ancak taşra teşkilatı tarafından yeterince önem veya zaman verilmeyen konular, ilgili personel gruplarının hizmet içi eğitime tabi tutulması ile yeniden gözden geçirilebilir. Aynı kapsamda, taşra teşkilatı tarafından yeterince önem veya zaman verilmeyen konular, üst yönetim tarafından diğer faaliyetlerle birleştirilebilir veya görev tanımından çıkartılabilir. Nitekim bu konu, Türkmen (1972)'de de belirtilmiş olup ilgili çalışmada gereksiz ve geçersiz iş ve işlemlerin ayıklanması, iş zaman analizlerine göre personel istihdamının saptanması ve reorganizasyonun da bu doğrultuda gerçekleş̧irilmesi konusu tartışılmıştır. Aynı durum bu araştırmada OZM ile ilgili faaliyetlerde ortaya çıkmış olup ilgili kesimlerin düşük önem atfettiği iş çeşitleri yeniden gözden geçirilebilir.

Kalıpsiz (1963), Türkmen (1972), Şafak (2008), Öztürk (2013) ve Şafak vd. (2015)'de belirtildiği gibi orman mühendisleri ile orman muhafaza memurlarının ormancılık faaliyetlerine yönelik görev ve sorumlulukları ile iş çeşidi ve yoğunlukları birbirinden farklıdır. Bu farklılık da doğal olarak faaliyetlere verilen önem ile ayrılan zaman düzeylerinin de birbirinden oldukça farklı olmasına neden olmaktadır.

OZM Faaliyetlerine verilen önem bakımından Faaliyet 1 (koruma ve orman suçlarının tespitine yönelik faaliyetler) ve Faaliyet 5 (orman kanununa aykırı eylemlerde tazminat hesaplamasına yönelik faaliyetler) dışındaki 12 faaliyette mevsimsel düzeyde farklılık tespit edilmemiştir. Koruma ve orman suçlarının tespitine yönelik faaliyetler (Faaliyet 1) ile daha çok bu faaliyetin sonucunda ortaya çıkan orman kanununa aykırı eylemlerde tazminat hesaplamasına yönelik 
faaliyetler (Faaliyet 5), süreklilik arz etmekle birlikte, kış aylarında araziye çıkılamadığından dolayı daha çok ilkbahar ve yaz aylarında yerine getirildiği araştırmadaki farklılık testi sonuçlarından görülmektedir.

Faaliyet 8 (zararlılarla mekanik mücadele faaliyetleri), Faaliyet 9 (zararlılarla biyolojik mücadele faaliyetleri), Faaliyet 10 (zararlılarla kimyasal mücadele faaliyetleri) ve Faaliyet 14 (koruma ve OZM konularındaki eğitim faaliyetleri) için mevsimsel farklılığın tespit edilememiş olması beklenmeyen bir sonuç olarak tespit edilmiştir. Nitekim bazı faaliyetler yıl içinde süreklilik arz ettiği için mevsimsel farklılık olmayabilir. Ancak Faaliyet 8, 9, 10'a yönelik çalışmalar daha çok ilkbahar ve yaz aylarında yapılmakta, Faaliyet 14 ise çoğunlukla arazi çalışmalarının yoğun olmadığı kış ve ilkbahar başlarında gerçekleştirilmektedir. Bu dört faaliyete, diğer faaliyetlere nazaran düşük önem atfedilmesi ve bunun içinde mevsimsel düzeyde aynı önem puanının verilmesi nedeniyle farklılaşma oluşmamış olabilir.

Orman mühendisleri ile orman muhafaza memurlarının 14 OZM faaliyetlerine verdikleri önem düzeyi bakımından mevsimsel farklılık bulunmamaktadır. Ancak adli arama faaliyetleri (faaliyet 2), orman kanununa aykırı eylemlerde tazminat hesaplaması (faaliyet 5), silah ve mermi teslimi, temini, kaybedilmesi vb. faaliyetlere (faaliyet 6), zararlılarla kimyasal mücadele faaliyetleri (faaliyet 10), karantina tedbirleri ve uygulamalarının yürütülmesine yönelik işler (faaliyet 11) ile muhafaza ormanlarının ayrılması ve idaresi ile ilgili iş ve işlemlerine (faaliyet 12) ayrılan zaman düzeyi bakımından orman mühendisleri ile orman muhafaza memurları arasında mevsimsel anlamda farklılık bulunmaktadır. Bu durum, Öztürk (2013) ve Şafak vd. (2015)'de belirtildiği gibi her iki kesimin sorumluluklarının, görev tanımlarının ve iş yoğunluklarının farklı olmasından kaynaklanabilir.

Araştırma sonuçları, Denizli Orman İşletme Müdürlüğü örneğinde elde edilmiş olup Ege Bölgesindeki işletmeler için benzer, ancak diğer bölgelerdeki işletmeler için iklim ve ekosistem farklılıkları nedeniyle farklı olacağı düşünülmektedir. $\mathrm{Bu}$ nedenle, diğer işletmelerde de geliştirilen anket formunun hem OZM hem de diğer ormancıllk faaliyetleri için mevsimsel olarak uygulanması durumunda daha sağlıklı sonuçlar elde edilecektir.

\section{Teşekkür}

Bu çalışmada Ege Ormancılık Araştırma Enstitüsü Müdürlüğünde "Denizli Orman İşletme Müdürlüğü İş Analizi” adıyla 2013-2015 yıllarında gerçekleştirilen araştırma sonucunda hazırlanan ve OGM Araştırma İhtisas Grupları Toplantısında yayınlanması yönünde karar verilen proje verilerinden yararlanılmıştır. Sonuç raporunda adları bulunan araştırmacılar Alper Tolga ARSLAN, Güven GÜLTEKİN ve Fazıl CABAROĞLU, bu makaledeki yayın hakkından feragat etmiş olup yardımları için teşekkür ederiz.

\section{Kaynaklar}

Alkan S., (2008), Orman mühendislerinin hizmet içi eğitim programlarını değerlendirmeler, 3. Ulusal Ormancılık Kongresi, 150. Yılında Türkiye'de Ormancılık Eğitimi, Ankara, ss.227-235.

Anıl Y., Çağlar Y., (1976), Orman bölge şefleri uzmanlık dallarının ayrılmasını istiyor, Orman Mühendisliği Dergisi, Yı1: 15, Sayı: 2, $7-8$.

Bircan H., (2005), Sağlık hizmetlerinde iş analizinin etkileri ve Zonguldak Atatürk Devlet Hastanesi uygulaması, Yüksek Lisans Tezi, Zonguldak Karaelmas Üniversitesi Sosyal Bilimler Enstitüsü, Zonguldak.

Çağlar Y., (1990), Türkiye'de orman mühendislerinin işlendirme sorunlarl ve çözüm öneriler, Orman Mühendisliği Dergisi, Sayı: 12, $50-55$.

Elvan D., (2005), Genel kolluk kuvvetlerinin ormanların korunmasında görev ve yetkileri, ïÜ Orman Fakültesi Dergisi, Seri B, Cilt 55, Sayı 2, 85-98.

Geray A.U., (2001), Ormancılık kurumları (2. yazım), Türkiye için ulusal programın hazırlanması projesi (TCP/TUR/0066(A), İstanbul, 76ss.

Kalıpsız A., (1963), Ormancllıkta teşkilat problemleri, İ̈̈ Orman Fakültesi Dergisi, Seri:B, Cilt. XIII, Sayı:I, 65-77.

OGM, (2009), Orman Genel Müdürlüğ̈̈ 2010-2014 Stratejik Plan, Ankara, 124ss.

Öztürk A., (2013), Orman Muhafaza Memurlarının Sorunları Üzerine Bir Araştırma, Artvin Çoruh Üniversitesi Orman Fakültesi Dergisi, Cilt: 14, Say1:2, 253-271.

Şafak İ., (2008), Ege bölgesi orman mühendislerinin profili, Orman Mühendisleri Odası Dergisi, Y1l:45, Sayı:10-11-12, Ankara, 2226.

Şafak İ., Göksu E., Gültekin G., Arslan A.T., Cabaroğlu F., (2015), Denizli orman işletme müdürlüğü iş analizi. Orman Genel Müdürlügü̈, Ege Ormanc1lık Araştırma Enstitüsü Müdürlüğü, İzmir,144ss.

TODAİE, (2002), TC Orman Genel Müdürlügü̈ yeniden yapılanma ve norm kadro projesi (cilt:3, önerilen yapı son rapor, merkez ve taşra teşkilatı), Türkiye ve Orta Doğu Amme İdaresi Enstitüsü, Ankara, 122ss.

Türker M.F., Öztürk A., Pak M., Durusoy İ., (2002), Orman Genel Müdürlüğ̈̈ yeniden yapılanma ve norm kadro araştırma projesi'ne ilişkin olarak kapsam, önem ve önceliğine bakılmaksızın yapılan genel değerlendirmeler, Orman Mühendisliği Dergisi, Cilt:39(6), 22-32.

Türkmen H., (1972), Orman bölge şefliklerinin reorganizasyonu ve bir anketin düşündürdükleri, Orman ve Av Dergisi, Cilt: 45, Say1: $6,17-20$.

URL-1, (2006), 5531 sayıl orman mühendisliği, orman endüstri mühendisliği ve ă̆aç işleri endüstri mühendisliği hakkında kanun, Resmi Gazete No: 26222, Yayın Tarihi: 8 Temmuz 2006, http://www.resmigazete.gov.tr/eskiler/2006/07/20060708-2.htm, [Erişim 1 Mart 2018]. 
URL-2, (1996), Orman muhafaza memurları görev ve çalışma esasları hakkında yönetmelik, 06.03 .1996 tarih ve 4 sayılı bakanlık oluru, https://www.ogm.gov.tr/ekutuphane/Yonetmelikler/Forms/DispForm.aspx?ID=57, [Erişim 1 Mart 2018].

URL-3, (2018), Denizli Orman Bölge Müdürlü̆̈̈̈ne bağll orman zararlılarl ile mücadele şube müdürlügünün görevleri, https://denizliobm.ogm.gov.tr, [Erişim 1 Mart 2018].

Yaman F., (2010), Ormancllıta örgütsel ve yönetsel başarlyı etkileyen faktörler, Yüksek Lisans Tezi, Bartın Üniversitesi, Fen Bilimleri Enstitüsü, Orman Mühendisliği Anabilim Dalı, Bartın.

Yavuz Ö., (2007), Orman genel müdürlügüüün personel yapısı ve sorunları, Yüksek Lisans Tezi, İÜ Fen Bilimleri Enstitüsü, Ormancılık Politikası ve Yönetimi Programı, İstanbul.

Yazıcı K., (1990), Türkiye'de orman mühendislerinin işlendirilmesi, Orman Mühendisliği Dergisi, Sayı: 12, 43-45.

Yomralığlu Ş., (1987), Orman işletmelerinin çağdaş örgütsel yapısl, Orman ve Av Dergisi, Cilt: 63, Sayı: 6, 11-17.

Yurdakul S., (2003). Ormancllıkta personel yönetimi sorunları ve sonuçları (örnek olaylarla irdeleme), Yüksek Lisans Tezi, İ̈̈ Fen Bilimleri Enstitüsü, Ormancılık Politikası ve Yönetimi Programı, İstanbul. 